Brit. J. prev. soc. Med. (1974), 28, 172-176

\title{
An epidemiological study of oesophageal atresia
}

\author{
T. J. DAVID* AND SARAH E. O'CALLAGHAN \\ Bristol General Hospital, Bristol BS1 6SY
}

\section{SUMMARY}

In a retrospective study of 227 cases of oesophageal atresia born in the south-west of England, the incidence was 0.34 per 1,000 births. Taking estimated dates of conception, there were no statistically significant yearly or monthly trends. There was a statistically significant winter excess of conceptions in the offspring of primigravidae but not multigravidae. Examination of the data for clustering, using a time-interval analysis, failed to show an increased risk of a case occurring within four weeks of a previous case. It is concluded that oesophageal atresia is aetiologically heterogeneous.

\section{INTRODUCTION}

The aetiology of oesophageal atresia (OA), with or without a tracheo-oesophageal fistula (TOF), is largely unknown. OA is a recognized but unusual feature of thalidomide embryopathy (Warkany, 1971). It is known to be associated with Down's syndrome (Holder, Cloud, Lewis, and Pilling, 1964) and trisomy E (Sommer and Grosfeld, 1970) though neither of these associations is particularly common. Perhaps the most notable feature of $O A$ is that over half the cases have other major malformations which are not confined to the gastrointestinal tract but commonly involve other systems.

The extreme rarity of familial recurrence of OA would seem to point to either non-recurrent or immunizing teratogens. With this in mind, the finding of clustering of dates of birth of cases of $\mathrm{OA}$ by Knox (1959) stands out as an important aetiological clue, supported by other hints of possible clustering by Kučera (1965) and Koop (1971). In this study data have been collected on patients born in the south-west of England with OA, with or without a TOF, and these data have been used to look for monthly, seasonal, and yearly trends as well as for clustering.

\section{SOURCES OF INFORMATION}

1. Lists of patients provided by thoracic surgeons at the two centres in the south-west where surgery for OA has been performed (Bristol and Exeter)

2. Diagnostic indices of medical records departments at the Bristol Royal Hospital for Sick Children and Frenchay Hospital, Bristol

3. Diagnostic indices compiled by paediatricians at Taunton and Exeter

4. Necropsy diagnostic indices at Southmead Hospital, Bristol, and the University of Bristolo Pathology Department

5. Hand searching of every necropsy report at Frenchay Hospital, Bristol, Musgrove Park Hos pital, Taunton, and the Royal Devon and Exeter Hospital, Exeter

6. Hand searching of admissions books for the special care baby units of the Bristol Royal Hospital for Sick Children, the Royal Devon and Exeter Hospital, Exeter, and Musgrove Park Hospital, Taunton

\section{Methods}

The hospital records of every live-born case were examined and, whenever possible, antenatal details were obtained from hospital antenatal records and from the general practitioner. The antenatal records were used in this study to estimate the date of conception of each case.

It is thought that nearly complete ascertainment has been achieved for (a) all live births with OA conceived in 1956 to 1972 (inclusive) in Devon, Somerset, Bristol, and Gloucestershire, and (b) all stillborn cases which came to necropsy conceived in 1956 to 1972 (inclusive) in Devon, Somerset, and Bristol. This gives a total of 227 cases, 19 of which were stillborn. The cases thought to be missed are firstly any stillborn or undiagnosed neonatal death cases in Gloucestershire, and 
secondly any other stillbirths or undiagnosed neonatal deaths which did not come to necropsy. One hundred and eighteen cases of OA were not included in this study because they fell outside the 1956 to 1972 time limits or were born in other counties in the south-west.

Information on live births and stillbirths, broken down by months, for Bristol was provided by the Bristol Public Health Department (by courtesy of Miss E. H. L. Duncan for 1956 to 1966, and Dr. A. J. Rowland and Mr. J. Haggett for 1967 to 1973). The monthly fluctuations for Bristol births (October 1956 to September 1973) were applied to the Registrar General's figures for births in Devon, Somerset, and Gloucestershire.

\section{RESULTS}

\section{INCIDENCE}

The figures used are given in Table $I$. The numbers for Bristol and Gloucestershire have been combined to eliminate possible errors involved in distinguishing between the County of Bristol and the Bristol Clinical Area. The total number of OA births (222) does not quite correspond with the total OA conceptions (227) given above and in
Table II, because 11 cases were not born until after the end of 1972, and six cases were born in 1956 but were conceived in 1955 .

\section{Yearly Fluctuations (CONCEPtions)}

There appears to be no linear trend either for the total cases or for the four areas taken separately (Table II). In no single area did the observed distribution of annual cases differ significantly from a Poisson distribution.

From the yearly figures it appears that there might be peaks in 1964, 1967, and 1969 which are fairly consistent in all four areas. However, using Friedman's two-way analysis of variance by ranks (Siegel, 1956), $\chi^{2}=21 \cdot 872, n=4, k=17$, which is not significant.

\section{Monthly Fluctuations (CONCEPTIONS)}

The data are given in Table III. The numbers in individual areas were too small to analyse with the $\chi^{2}$ test, but for the four areas taken together the results were:

(a) on the null hypothesis that the same number of cases should be conceived in each calendar month, $\chi^{2}(11)=13 \cdot 5=$ not significant.

TABLE I

INCIDENCE OF OESOPHAGEAL ATRESIA IN SOUTH-WEST OF ENGLAND, 1956-72

\begin{tabular}{|c|c|c|c|c|c|c|}
\hline County & & Cases Born & Live Births & Still Births & Total Births & Incidence per 1,000 \\
\hline $\begin{array}{ll}\text { Devon } & \ldots \\
\text { Somerset } & \ldots \\
\text { Bristol } & \therefore \\
\text { Gloucestershire }\end{array}$ & $\begin{array}{l}\ddot{*} \\
\ddot{*} \\
\ddot{*}\end{array}$ & $\begin{array}{l}61 \\
56 \\
73 \\
32 \\
\end{array}$ & $\begin{array}{l}200,990 \\
154,940 \\
111,356 \\
170,625\end{array}$ & $\begin{array}{l}3,255 \\
2,600 \\
1,674 \\
2,707\end{array}$ & $\left.\begin{array}{l}204,245 \\
157,540 \\
113,030 \\
173,332\end{array}\right\}$ & $\begin{array}{l}0 \cdot 30 \\
0 \cdot 36 \\
0 \cdot 37\end{array}$ \\
\hline Total & $\cdots$ & 222 & & & 648,147 & $0 \cdot 34$ \\
\hline
\end{tabular}

TABLE II

NUMBER OF CASES OF OESOPHAGEAL ATRESIA CONCEIVED EACH YEAR, BY AREA OF BIRTH

\begin{tabular}{|c|c|c|c|c|c|c|c|}
\hline & Year & & Devon & Somerset & Bristol & Gloucestershire & Total \\
\hline $\begin{array}{l}1956 \\
1957 \\
1958 \\
1959 \\
1960 \\
1961 \\
1962 \\
1963 \\
1964 \\
1965 \\
1966 \\
1967 \\
1968 \\
1969 \\
1970 \\
1971 \\
1972\end{array}$ & 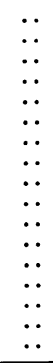 & 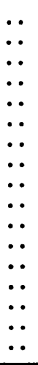 & $\begin{array}{l}1 \\
4 \\
5 \\
5 \\
1 \\
1 \\
5 \\
2 \\
5 \\
3 \\
4 \\
5 \\
4 \\
4 \\
5 \\
4 \\
4\end{array}$ & $\begin{array}{l}4 \\
3 \\
3 \\
1 \\
2 \\
2 \\
4 \\
3 \\
6 \\
3 \\
2 \\
6 \\
4 \\
6 \\
2 \\
4 \\
3\end{array}$ & $\begin{array}{l}6 \\
6 \\
4 \\
4 \\
4 \\
6 \\
3 \\
4 \\
8 \\
2 \\
5 \\
6 \\
1 \\
8 \\
2 \\
3 \\
0\end{array}$ & $\begin{array}{l}1 \\
1 \\
2 \\
1 \\
0 \\
1 \\
3 \\
1 \\
2 \\
4 \\
3 \\
3 \\
1 \\
3 \\
1 \\
3 \\
5\end{array}$ & $\begin{array}{r}12 \\
14 \\
14 \\
11 \\
7 \\
10 \\
15 \\
10 \\
21 \\
12 \\
14 \\
20 \\
10 \\
21 \\
10 \\
14 \\
12\end{array}$ \\
\hline Total & $\ldots$ & . & 62 & 58 & 72 & 35 & 227 \\
\hline
\end{tabular}


TABLE III

MONTH OF CONCEPTION, BY AREA OF BIRTH, 1956-72

\begin{tabular}{|c|c|c|c|c|c|c|c|}
\hline \multicolumn{3}{|c|}{ Month } & Devon & Somerset & Bristol & Gloucestershire & Total \\
\hline $\begin{array}{l}\text { January } \\
\text { February } \\
\text { March } \\
\text { April } \\
\text { May } \\
\text { June } \\
\text { July } \\
\text { August } \\
\text { September } \\
\text { October } \\
\text { November } \\
\text { December }\end{array}$ & $\begin{array}{l}\ldots \\
\cdots \\
\cdots \\
\cdots \\
\cdots \\
\cdots \\
\cdots \\
\cdots\end{array}$ & $\begin{array}{l}\cdots \\
\cdots \\
\cdots \\
\cdots \\
\cdots \\
\cdots \\
\cdots \\
\cdots\end{array}$ & $\begin{array}{r}11 \\
4 \\
4 \\
1 \\
2 \\
4 \\
9 \\
7 \\
2 \\
6 \\
8 \\
4\end{array}$ & $\begin{array}{r}4 \\
6 \\
6 \\
2 \\
9 \\
11 \\
2 \\
4 \\
5 \\
4 \\
3 \\
2\end{array}$ & $\begin{array}{r}5 \\
10 \\
9 \\
3 \\
5 \\
4 \\
6 \\
6 \\
7 \\
6 \\
6 \\
5\end{array}$ & $\begin{array}{l}3 \\
1 \\
3 \\
1 \\
6 \\
5 \\
3 \\
2 \\
2 \\
4 \\
3 \\
2\end{array}$ & $\begin{array}{r}23 \\
21 \\
22 \\
7 \\
22 \\
24 \\
20 \\
19 \\
16 \\
20 \\
20 \\
13\end{array}$ \\
\hline Total & . & .. & 62 & 58 & 72 & 35 & 227 \\
\hline
\end{tabular}

(b) Comparing the number of cases conceived in a month with the estimated number of births in a month (nine months later),

$$
\chi^{2}(11)=13 \cdot 7=\text { not significant. }
$$

(c) Edwards' (1961) test for detecting cyclic trends failed to detect one, the figures for all four areas taken together being $\chi^{2}=0 \cdot 14, \theta=219$ degrees, sampling variance $=0.008811$.

(d) There was a small excess of winter conceptions (119 to 108) which was not statistically significant $\left(\chi^{2}\right.$ values were calculated for deviations from the distribution that would be expected if there were no seasonal variation.) The maternal parity of 216 of the 227 cases was known, and dividing the cases into offspring of primigravidae and multigravidae, the winter excess was confined to the offspring of primigravidae (55 to $37, \chi^{2}(1)=3 \cdot 5=$ not significant) and was not shown by the offspring of the multigravidae (59 to 65). Because the winter excess in offspring of primigravidae was only just below a statistically significant level, the search for a winter excess was extended to the whole series of 345 cases, of whom the parity of the mother was known in 303. For this whole group there was a statistically significant winter excess, 171 to $132, \chi^{2}(1)=5.0, P<0.05$. Taking the offspring of multigravidae alone, there was barely a winter excess, 91 to 90 , but taking the offspring of primigravidae alone, there was a statistically significant winter excess, 80 to 42 , $\chi_{(1)}=11.8, P<0.001$.

\section{Time Clustering (Conceptions)}

The Knox (1959) time interval analysis method was applied, not to dates of birth but to estimated dates of conception. All four areas were taken together and were analysed both with sexes separate
TABLE IV

TIME INTERVAL ANALYSIS BASED ON ESTIMATED DATES OF CONCEPTION OF 227 CASES CONCEIVED BETWEEN 1 JANUARY 1956 AND 31 DECEMBER 1972 AND BORN IN DEVON, SOMERSET, BRISTOL, OR GLOUCESTERSHIRE

\begin{tabular}{l|ccccc}
\hline & \multicolumn{5}{|c}{ No. of Days after Index Case } \\
\cline { 2 - 7 } & $0-6$ & $7-13$ & $14-20$ & $21-27$ & $28-41$ \\
\hline Interval & 7 & 7 & 7 & 7 & 14 \\
\hline Observed & 63 & 62 & 42 & 67 & 129 \\
Expected & $57 \cdot 8$ & $57 \cdot 8$ & $57 \cdot 8$ & $57 \cdot 8$ & $115 \cdot 7$ \\
Excess & $5 \cdot 2$ & $4 \cdot 2$ & $-15 \cdot 8$ & $9 \cdot 2$ & $13 \cdot 3$ \\
& & & & & \\
\hline
\end{tabular}

and sexes combined (Table IV). The results do not show any increased risk of a case occurring within four weeks of a previous case.

\section{Discussion}

The figure of 0.34 per 1,000 births for the incidence of OA obtained in this study is slightly higher than any previously published figures based on at least 30 cases (see Table V), and this is probably because stillborn cases have been included. So far, information is inadequate to tell if there is any geographical variation in the incidence of OA.

It has not been possible to detect a statistically significant yearly trend for conceptions of cases of OA. It seems likely that Knox's (1959) statistically significant result (on births) arose from a combination of (a) incomplete ascertainment, and (b) a quite definite epidemic in one year, as far as Birmingham is concerned. Nonetheless, the annual numbers of cases do vary, and the actual figures are given here in the hope that the variation may be found to point to some unknown environmental agent.

It was not possible to detect a statistically significant monthly trend, though it is interesting that 17 out of the 21 twins with $O A$ in this 
TABLE V

INCIDENCE OF OESOPHAGEAL ATRESIA

\begin{tabular}{|c|c|c|c|}
\hline Incidence & No. of Cases & Place & Reference \\
\hline $\begin{array}{l}0 \cdot 30 \text { per } 1,000 \text { live births } \\
0 \cdot 25 \text { per } 1,000 \text { total births } \\
0 \cdot 28 \text { per } 1,000 \text { live births } \\
0 \cdot 22 \text { per } 1,000 \text { live births } \\
0 \cdot 34 \text { per } 1,000 \text { total births }\end{array}$ & $\begin{array}{r}30 \\
52 \\
36 \\
328 \\
222\end{array}$ & $\begin{array}{l}\text { Helsinki } \\
\text { Birmingham } \\
\text { Gothenburg } \\
\text { Victoria (Australia) } \\
\text { Devon, Somerset, Bristol, } \\
\text { and Gloucestershire }\end{array}$ & $\begin{array}{l}\text { Sulamaa, Gripenberg, and } \\
\text { Ahvenainen (1952) } \\
\text { Leck, Record, McKeown, and } \\
\text { Edwards (1968) } \\
\text { Henrikson and Petterson (1970) } \\
\text { Myers (1973) } \\
\text { Present study }\end{array}$ \\
\hline
\end{tabular}

series were conceived in the six-month period June to November (David and O'Callaghan, in press).

Slater, Watson, and McDonald (1964) reported a statistically significant winter excess of births with OA, but not for TOF. It is not clear why these two lesions were treated separately since they nearly always coexist. Presumably some doctors labelled a case OA, while others called a case TOF, causing this apparent confusion. In the present study a winter excess of conceptions was found, and this was due to a winter excess in the offspring of primigravidae. No explanation is offered for this strange finding which requires confirmation before there is any speculation.

It has not been possible to confirm Knox's (1959) positive time-clustering result. The only difference in our method was to use the estimated dates of conception rather than dates of birth. This was done because of the extremely variable duration of gestation in OA, and dates of conception therefore seemed more meaningful. Despite this drawback to Knox's data, and despite the incomplete ascertainment of his series, his positive results are not satisfactorily explained by these methodological differences.

Over half of all cases of OA have other malformations apart from a TOF, which are often serious or fatal. There are several different patterns of associated malformations, and it is at least conceivable that $\mathrm{OA}$ is a rather non-specific consequence of several teratologic processes. This creates considerable difficulties when trying to compare the findings in this study with others, since other series may not contain the same mixture of aetiologically different subgroups. Progress in the future will depend on the ability to recognize aetiological entities within a group of apparently similar malformations. An attempt in this direction, though for a different reason, has been made by Quan and Smith (1973) who have recognized an entity called the VATER association of Vertebral, Anal, Tracheal, Esophageal, and Radial limb defects. This approach has been taken further by Nora and Nora (1973) with their
VACTEL association of Vertebral, Anal, Cardiac, Tracheal, Esophageal, and Limb defects, and these authors suggest that the VACTEL association may be caused by oral hormone preparations. However, as with Down's syndrome, for example, these associations account for only a small fraction of the total cases of OA. In the present series of 345 cases, four had Down's syndrome, two others had the VATER association, and no case nad the VACTEL association. Yet Nora and Nora (1973) were able to report no less than 10 cases of the VACTEL association (drawn from an undefined population). This clearly underlines the aetiological heterogeneity of clinical groupings, making it impossible to say, for example, whether there is any conflict between Knox's (1959) positive and our negative results for time clustering.

We are very grateful to Miss E. H. L. Duncan, Mrs. A. F. Morris, Dr. R. E. Midwinter, and Professor E. G. Knox for their kind comments. TJD is in receipt of a grant from the Medical Research Council.

\section{REFERENCES}

Belsey, R. H. R. and Donnison, C. P. (1950). Congenital atresia of the oesophagus. Brit. med. J., 2, 324.

David, T. J. and O'Callaghan, S. E. (1974). Twinning and oesophageal atresia. Arch. Dis. Childh. (In press).

EDWARDS, J. H. (1961). The recognition and estimation of cyclic trends. Ann. hum. Genet., 25, 83.

Henrikson, B. and Petterson, G. (1970). Oesophageal atresia. Z. Kinderchir., 8, 209.

Holder, T. M., Cloud, D. T., Lewis, J. E., and Pilling, G. P. (1964). Esophageal atresia and tracheoesophageal fistula. A survey of its members by the Surgical Section of the American Academy of Pediatrics. Pediatrics, 34, 542.

KNoX, G. (1959). Secular pattern of congenital oesophageal atresia. Brit. J. prev. soc. Med., 13, 222.

Koop, C. E. (1971). Recent advances in the surgery of oesophageal atresia. In: Progress in Pediatric Surgery, Vol. 2., edited by P. P. Rickham, W. C. Hecker, and J. Prevot, University Park Press, Baltimore. 
KUČERA, J. (1965). Shlukování vrozených vadnepř́mý dúkaz zevní płrǐ̌iny jejich vzniku? Cs. Pediat., 20, 873.

LeCK, I., ReCORD, R. G., McKeown, T., and EDWARDS, J. H. (1968). The incidence of malformations in Birmingham, England, 1950-1959. Teratology, 1, 263.

MYERS, N. A. (1973). Oesophageal atresia-the epitome of modern surgery. Royal College of Surgeons of England Hunterian Lecture delivered on 24 July.

NorA, J. J. and NorA, A. H. (1973). Birth defects and oral contraceptives. Lancet, 1, 941. [A letter].

QuAN, L. and SMith, D. W. (1973). The VATER association. Vertebral defects, Anal atresia, T-E fistula with esophageal atresia, Radial and Renal dysplasia: a spectrum of associated defects. J. Pediat., 82, 104.
Sirger, S. (1956). Nonparametric Statistics for the Behavioral Sciences, pp. 166-173. McGraw-Hill, New York.

Slater, B. C. S., Watson, G. I., and McDonald, J. C. (1964). Seasonal variation in congenital abnormalities. Preliminary report of a survey conducted by the research committee of Council of the College of General Practitioners. Brit. J. prev. soc. Med., 18, 1. SOMmer, A. and Grosfeld, J. L. (1970). Trisomy E and T-E fistula. J. med. Genet., 7, 70.

SulamaA, M., Gripenberg, L., and AhVenainen, E. K. (1952). Prognosis and treatment of congenital atresia of the esophagus. Acta Chir. scand., 102, 141.

WARKanY, J. (1971). Congenital Malformations: Notes and Comments, p. 678. Year Book Medical Publishers, Chicago. 